\title{
Female Library Science Students And the Occupational Stereotype: Fact or Fiction?
}

\begin{abstract}
Mass media stereotype the librarian pejoratively as compared with other professionals. In a personality comparison of a group of female library science students with a general college student norm, both groups ranked similarly. In some cases, the prospective librarians ranked more favorably than did college students.
\end{abstract}

$\mathrm{T}$ HE NEGATIVE IMAGE OF THE LIBRARIAN has recently been exploited in mass media. For example, Publisher's Weekly reported on an American Motors ad which stated: "We may lose a few librarians for customers, but we think we'll gain a few enthusiasts."1 Ironically, professional journals publish titles that also cast a negative image of the librarian. Titles such as "Has Marian the Librarian Changed?," "What Would You Do With Brighter People?" and "The New Morality and the Old Librarian" help to encourage the continuance of the occupational stereotype. ${ }^{2}$ Sable wrote a description of the stereotype as follows:

She's a she, wears a long, unfashionable dress down to her calves, sits at a desk in view of all library users with a crabbed, tightly pursed look upon her face. Bespectacled, hair pulled back behind her ears, she is unfailingly and eternally middle aged, unmarried and most uncommunicative. She exists to put a damper on all spontaneity, silencing the exuberance of the young with a harsh look or hiss of air ... an ultimately pitiable figure with no outside interest. ${ }^{3}$

$\mathrm{Mr}$. Lee is director of testing, North $\mathrm{Da}$ kota Department of Public Instruction; Ms. Hall is a graduate student, University of North Dakota, Bismarck.
The stereotype could be used to infer that prospective librarians would not be similar to typical college students. The validity of the occupational stereotype for prospective librarians can be tested in a comparison of their personality characteristics and those of the typical college student. Specifically, the following research question can be asked: "What are the mean differences between a group of female prospective librarians and a female college norm group on certain personality characteristics as measured by the Sixteen Personality Factor Questionnaire (16 PF)?”

\section{METHOD}

Because much literature that stereotypes librarians has lacked verification, it was deemed essential to conduct an empirical study. Group means of the 16 . $\mathrm{PF}$ were compared between a group of female prospective librarians at the University of North Dakota and a female college norm group. ${ }^{4}$ The means on each of the sixteen factors for these two groups was first compared by profile inspection, which showed (1) if the prospective librarians scored outside the average range of scores for the female college norm group; and (2) if the prospective librarians conformed to the occupational stereotype. This procedure: 
was followed by computation of unrelated $t$ tests for the two sets of group means. ${ }^{5}$ Finally, a profile similarity coefficient, rp, as devised by Cattell and Eber, was calculated to determine the degree of similarity between the two sets of profiles. ${ }^{6}$

The subjects consisted of forty-five female library science students enrolled at the University of North Dakota during the 1970-71 fall semester. Included in this sample were fifteen graduate students and thirty undergraduate students. The subjects ranged in age from 18 to 58 with a mean age of 25.69 and a standard deviation of 9.55. (See Table 1.)

The scales are measured by a sten score which is a standard score with equal intervals from one through ten. Based on a mean sten score of 5.50 for the female college norm group, the average scores on the profile range from 4.75 to 6.25 . Scores below 4.75 would tend toward the first word listed for that factor and scores above 6.25 would tend toward the second word listed.

\section{REsUlts}

Examination of Table 1 reveals that the mean sten scores for the subjects were all above 4.75 and this not in the direction of the low score description for each scale. (Furthermore, on thirteen of the sixteen scales, the subjects' mean sten scores were within .48 of the female college norm group mean. It appears that the responses of these prospective librarians were quite similar to the female college norm group responses.)

Table 2 shows whether prospective librarians conform to the occupational stereotype as compared to the college norm group.

A comparison of group means between the prospective librarians and the norm group revealed that there were significant differences (.01) on factors $B, Q_{1}$, and $Q_{2}$. On these scales of intelligence, experimentation, and self-sufficiency the prospective librarians scored higher than the norm group. Furthermore, Table 2 shows a profile similarity coefficient of .95 , indicative of similar profiles between the two groups.

\section{Discussion}

As this study was limited to female prospective librarians enrolled at the University of North Dakota during one semester, no attempt should be made to generalize these findings to all female

TABLE 1

16 Personality Factor Questionnaire, Female Prospective Librarians Subject Means and Standard Deviations

\begin{tabular}{|c|c|c|c|c|c|}
\hline Factor & Low Score & Description & High Score & $\begin{array}{l}\text { Subject } \\
\text { Means }\end{array}$ & $\begin{array}{l}\text { Subject Standard } \\
\text { Deviations }\end{array}$ \\
\hline A & RESERVED & 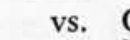 & OUTGOING & 5.33 & 2.00 \\
\hline B & LESS INTELLIGENT & vs. 1 & MORE INTELLIGENT & 6.75 & 1.90 \\
\hline C & AFFECTED BY FEELINGS & $S$ vs. $\mathrm{I}$ & EMOTIONALLY STABLE & 5.24 & 1.64 \\
\hline $\mathrm{E}$ & HUMBLE & vs. & ASSERTIVE & 5.62 & 2.34 \\
\hline $\mathbf{F}$ & SOBER & vs. I & HAPPY-GO-LUCKY & 5.64 & 1.90 \\
\hline G & EXPEDIENT & vs. & CONSCIENTIOUS & 5.44 & 1.93 \\
\hline $\mathrm{H}$ & SHY & vs. I & VENTURESOME & 5.02 & 1.98 \\
\hline I & TOUGH-MINDED & vs. 7 & TENDER-MINDED & 5.69 & 2.13 \\
\hline $\mathrm{L}$ & TRUSTING & vs. S & SUSPICIOUS & 5.37 & 1.67 \\
\hline$\vec{M}$ & PRACTICAL & vs. I & IMAGINATIVE & 5.87 & 1.85 \\
\hline $\mathrm{N}$ & FORTHRIGHT & vs. S & SHREWD & 5.16 & 1.97 \\
\hline $\mathrm{O}$ & SELF-ASSURED & vs. $A$ & APPREHENSIVE & 5.71 & 1.53 \\
\hline$Q_{1}$ & CONSERVATIVE & vs. $\mathrm{E}$ & EXPERIMENTING & 6.49 & 1.70 \\
\hline $\mathrm{Q}_{2}$ & GROUP-DEPENDENT & vs. S & SELF-SUFFICIENT & 6.38 & 1.79 \\
\hline $\mathrm{Q}_{3}$ & CASUAL & vs. C & CONTROLLED & 5.31 & 2.27 \\
\hline Q. & RELAXED & vs. & TENSE & 5.91 & 1.86 \\
\hline
\end{tabular}


TABLE 2

Means of Difference and t Tests Between Female Library Science Students $(\mathrm{N}=45)$ and the College Female Norm Group $(\mathrm{N}=1012)$

\begin{tabular}{lrrr}
\hline \hline Factor & $\begin{array}{c}\text { Means of } \\
\text { Difference }\end{array}$ & \multicolumn{1}{c}{$\mathrm{t}$} & $\begin{array}{c}\mathrm{p} \\
\text { Level }\end{array}$ \\
\hline $\mathrm{A}$ & -.17 & -.55 & $\mathrm{~ns}$ \\
$\mathrm{~B}$ & 1.25 & 4.25 & .01 \\
$\mathrm{C}$ & -.26 & -1.02 & $\mathrm{~ns}$ \\
$\mathrm{E}$ & .12 & .34 & $\mathrm{~ns}$ \\
$\mathrm{~F}$ & .14 & .48 & $\mathrm{~ns}$ \\
$\mathrm{G}$ & -.06 & -.20 & $\mathrm{~ns}$ \\
$\mathrm{H}$ & -.48 & -1.57 & $\mathrm{~ns}$ \\
$\mathrm{I}$ & .19 & .56 & $\mathrm{~ns}$ \\
$\mathrm{~L}$ & -.13 & -.50 & $\mathrm{~ns}$ \\
$\mathrm{M}$ & .37 & 1.29 & $\mathrm{~ns}$ \\
$\mathrm{~N}$ & -.34 & -1.12 & $\mathrm{~ns}$ \\
$\mathrm{O}$ & .21 & .88 & $\mathrm{~ns}$ \\
$\mathrm{Q}_{1}$ & .99 & 3.76 & .01 \\
$\mathrm{Q}_{2}$ & .88 & 3.17 & .01 \\
$\mathrm{Q}_{3}$ & -.19 & -.55 & $\mathrm{~ns}$ \\
$\mathrm{Q}_{4}$ & .41 & 1.42 & $\mathrm{~ns}$ \\
& $\mathrm{D}^{2}=4.24$ & & \\
\hline
\end{tabular}

Note-The signs on means of difference indicate the direction of scores from the college female norm group mean of 5.50 .

prospective librarians or to all departments of library science.

Since the mean scores for the subjects on thirteen of the sixteen scales were within the average range and the mean scores for the other three scales were in a favorable direction above the average range, it is evident that the occupational stereotype failed to receive any support from the results of this study. Rather, in contrast to the occupational stereotype, this group of library science students was not found to be more rigid, conscientious, conventional, conservative, tense, or less intelligent and less stable than the college female norm group. In addition, three scores on the scales which revealed statistical differences between the groups (More Intelligent, Experimenting, Self-Sufficient) were favorable to prospective librarians.

Interpretation of these results seems to indicate that further empirical study could compare occupational group profiles and to ascertain the validity of assumptions regarding occupational stereotypes. Future research could concentrate on larger samples of both sexes from a wide geographical distribution and also include people working in occupations as well as prospective workers.

\section{REFERENCES}

1. "Confession of Error," Publisher's Weekly 199:28 (18 Jan. 1971).

2. H. Deutsch, "Has Marian the Librarian Changed?" New York State Educational Journal 54:26-27 (1967); M. Kraft, "What Would You Do With Brighter People?" Journal of Education for Librarianship 7:21-28 (Summer 1966); E. M. Oboler, "The New Morality and the Old Librarian," ALA Bulletin 62:1369-73 (Dec. 1968).

3. A. P. Sable, "The Sexuality of the Library Profession," Wilson Library Bulletin 43: 748-51 (April 1969).
4. R. B. Cattell and H. W. Eber, Manual for the Sixteen Personality Factor Questionnaire (Champaign, Ill.: Institute for Personality and Ability Testing, 1962).

5. B. J. Underwood, C. P. Duncan, J. A. Taylor, and J. W. Cotton, Elementary Statistics (New York: Appleton-Century-Crofts, 1954).

6. R. B. Catell and H. W. Eber, Handbook for the Sixteen Personality Factor Questionnaire (Champaign, Ill.: Institute for Personality and Ability Testing, 1957). 